\title{
Efek Moringa oleifera terhadap Gula Darah dan Kolagen Matrik Ekstraseluler Sel 6 Pankreas Diabetes Eksperimental
}

\section{The Effect of Moringa oleifera on Blood Glucose and Collagen of Extra Cellular Matrix 6 Cell Pancreas on Diabetic Experiment}

\author{
Ambarwati $^{1}$, Sarjadi ${ }^{2}$, Andrew Johan ${ }^{3}$, Kis Djamiatun $^{4}$ \\ ${ }^{1}$ Akademi Keperawatan Krida Husada Kudus \\ ${ }^{2}$ Bagian Patologi Anatomi Fakultas Kedokteran Universitas Diponegoro \\ ${ }^{3}$ Bagian Biokimia Fakultas Kedokteran Universitas Diponegoro \\ ${ }^{4}$ Program Studi Magister Ilmu Biomedik Fakultas Kedokteran Universitas Diponegoro
}

\begin{abstract}
ABSTRAK
Daun Moringa oleifera mengandung zat-zat bioaktif yang memperbaiki dan merangsang sel $\beta$ pankreas untuk mensekresi insulin yang mengatur kadar gula darah. Kelangsungan hidup dan fungsi sel $\beta$ pankreas memerlukan matriks ekstraseluler (ECM) yaitu fibronektin, laminin dan kolagen. Apakah kadar gula dan kolagen ECM yang mungkin terpengaruh streptozotocin yang merusak sel $\beta$ pankreas diteliti pada diabetes eksperimental yang diberi perlakukan M.oleifera. Studi ini menggunakan 24 tikus. Kadar gula darah diukur sebelum dan sesudah induksi streptozotocin 2 hari yang berdampak hiperglikemi, sesudah itu tikus dibagi menjadi 4 kelompok yang terdiri dua grup kontrol yang diterminasi pada hari 0 dan 21 hiperglikemi, dan dua kelompok diperlakukan dengan ekstrak daun M.oleifera dosis 250 dan 500mg/kg BB/hari selama 21 hari. Data dianalisis dengan statistik parametrik dan non-parametrik. Taraf kemaknaan $p<0,05$. Kadar gula menurun pada masing-masing kelompok perlakukan dosis 250 dan $500 \mathrm{mg} / \mathrm{BB} / \mathrm{kg} \mathrm{BB} / \mathrm{hari}(p=0,000)$. Kadar gula menjadi normal pada kelompok perlakuan dosis $500 \mathrm{mg} / \mathrm{kg}$ BB/hari. Ketebalan kolagen ECM pulau Langerhans pankreas tetap normal di semua kelompok penelitian. Ekstrak daun M.oleifera dosis $500 \mathrm{mg} / \mathrm{kg} \mathrm{BB/hari} \mathrm{adalah} \mathrm{dosis} \mathrm{efektif} \mathrm{untuk} \mathrm{menormalkan}$ kadar gula darah pada diabetes eksperimental.
\end{abstract}

Kata Kunci: Diabetes melitus, kadar gula darah, ketebalan kolagen ECM, Moringa oleifera, Streptozotocin, sel $\beta$ pankreas

\begin{abstract}
Moringa oleifera leaves contain bioactive substances which regenerate and stimulate $B$ cell pancreas for secreting insulin which regulates blood glucose levels. Survival and function of $B$ cells need extra cellular matrix (ECM) namely fibronectin, laminin and collagen. Whether glucose level or ECM collagen which might be affected by streptozotocin harming $B$ cell of pancreas was studied in experimental diabetes treated with M.oleifera. This study used 24 rats. Blood glucose was measured before and after 2 days of streptozotocin induction confirming hyperglycemias, subsequently the rats were divided into 4 groups in which two control groups were terminated on day 0 and day 21 hyperglycemias, and two groups treated with M.oleifera leaf extract in dose of 250 and $500 \mathrm{mg} / \mathrm{kgBW} /$ day for 21 days. Parametric and non parametric statistical analyses were used. Significance level is $p<0,05$. Glucose levels declined in groups treated with dose of 250 and $500 \mathrm{mg} / \mathrm{kgbw} /$ day. Glucose levels were normal in those received dose of $500 \mathrm{mg} / \mathrm{kg} b \mathrm{w} /$ day. Collagen thickness of ECM langerhans island pancreas remained normal in all observed groups. M.oleifera leaf extract in dose of $500 \mathrm{mg} / \mathrm{kg} b \mathrm{w} / \mathrm{day}$ is the effective dose for normalizing blood glucose levels in diabetic experiment.
\end{abstract}

Keywords: 8 cells pancreas, blood sugar levels, diabetes mellitus, Moringa oleifera, Streptozotocin, thickness of collagen ECM

Jurnal Kedokteran Brawijaya, Vol. 28, No. 2, Agustus 2014: Ambarwati. Akademi Keperawatan Krida Husada Kudus, Jl. Lambao Singocandi No 1 Kudus Tel.(0291)432613 Email:ambar_wati45@yahoo.co.id 


\section{PENDAHULUAN}

Perkiraan prevalensi DM di seluruh dunia pada dewasa (usia 20-79 tahun) sebanyak 6,4\% atau 285 juta orang pada tahun 2010 dan akan meningkat menjadi 7,7\% atau 439 juta orang pada 2030. Indonesia menempati urutan ke-9 dalam estimasi epidemiologi DM dunia pada tahun 2010 dengan 7 juta kasus dan akan naik menjadi peringkat ke-6 pada tahun 2030 dengan 12 juta kasus (1).

Penegakan diagnosis diabetes melitus dapat dilakukan jika kadar gula darah sewaktu mencapai $\geq 200 \mathrm{mg} / \mathrm{dL}$ atau gula darah puasa $\geq 126 \mathrm{mg} / \mathrm{dL}$ yang disertai gejala khas (poliuria, polidipsia, polifagia) dan berat badan menurun tanpa sebab yang jelas (2). Kadar gula darah yang tinggi dan berlangsung lama dapat menimbulkan komplikasi yaitu perubahan morfologik di arteri (aterosklerosis), membran basal pembuluh darah (mikroangiopati), ginjal (nefropati diabetes), retina (retinopati), saraf (neuropati) dan jaringan lain (3).

Hiperglikemia yang terus menerus menyebabkan peningkatan produksi reactive oxygen species (ROS) di semua jaringan dari autooksidasi glukosa dan glikosilasi protein. Kadar enzim antioksidan sangat mempengaruhi kerentanan berbagai jaringan pada stres oksidatif dan dikaitkan dengan perkembangan komplikasi dalam diabetes (4). Penelitian lain menunjukkan bahwa hiperglikemia meningkatkan stres oksidatif melalui produksi berlebih dari ROS, yang menghasilkan suatu ketidakseimbangan antara oksidan dan sistem pertahanan antioksidan dalam sel (5).

Sel beta pankreas penting untuk respon cepat dan tepat terkendali untuk perubahan kadar glukosa darah. Gangguan fungsi sel $\beta$ pankreas menyebabkan diabetes melitus. Kelangsungan hidup dan fungsi sel $\beta$ yang baik, memerlukan matriks ekstraseluler (ECM) yaitu fibronektin, laminin dan kolagen I dan IV dan reseptor mereka yaitu integrins. Tujuh subunit $\alpha$ terkait dengan subunit integrin $\beta 1$ telah diidentifikasi, termasuk $\alpha$ 1-6 dan $\alpha$ V. Diantara heterodimers ini, $\alpha 3 \beta 1$ paling tinggi ekspresinya. Ligan yang umum untuk integrin $\alpha 3 \beta 1$, termasuk fibronektin, laminin, kolagen I dan kolagen IV telah diuji dalam penelitian in vitro untuk mengidentifikasi matriks paling cocok untuk proliferasi dan fungsi sel insulinoma. Sel insulinoma yang terpapar kolagen I dan IV menunjukkan peningkatan yang signifikan dalam adhesi, spreading, viabilitas sel, proliferasi dan focal adhesi contact (FAK) fosforilasi bila dibandingkan dengan sel insulinoma yang terpapar fibronektin, laminin dan kontrol (6).

Streptozotocin (STZ) adalah bahan kimia toksik yang sering dipakai pada penelitian hewan coba diabetes, yang akan menginduksi kerusakan sel beta pankreas melalui alkilasi DNA dengan pembentukan $\mathrm{H}_{2} \mathrm{O}_{2}$ dan reaksi inflamasi. Streptozotocin bekerja toksik terhadap sel beta pankreas memerlukan pengambilan STZ ke dalam sel. Streptozotocin terakumulasi dalam sel beta pankreas melalui afinitas rendah dari transporter glukosa $\left(G L U T_{2}\right)$ di membran plasma (7).

Moringa oleifera (Kelor) adalah tanaman di Indonesia yang telah banyak dimanfaatkan masyarakat di beberapa daerah untuk sayuran dan obat tradisional untuk mengobati cacingan, diabetes, hipertensi (8). Ekstrak etanol daun kelor mempunyai kandungan kimia antara lain flavanoids, tannin, anthraquinone, cardiac glycosides alkaloids, triterpenoids, saponins, and reducing sugars (9). Komponen bioaktif Moringa oleifera (MO) pada daun adalah 4-(alpha-l-rhamnopyranosyloxy)benzylglucosinolate, quercetin-3-O-glucoside, quercetin3-O-(6"-malonyl-glucoside) dan yang lebih rendah ialah kaempferol-3-O-glucoside, dan kaempferol-3-O-(6"'malonyl-glucoside), 3-caffeoylquinic acid, 5caffeoylquinic acid (10). Ekstrak daun kelor dapat menurunkan kadar gula darah meningkatkan kadar antioksidan dalam jaringan pankreas dan secara signifikan memulihkan kerusakan histoarsitektural pada islet pankreas $(9,11,12)$. Penelitian ini bertujuan membuktikan kadar gula darah dan ketebalan kolagen pada ECM sel $\beta$ pulau Langerhans pankreas akibat pemberian ekstrak etanol daun Moringa oleifera pada tikus Sprague-dawley yang diinduksi streptozotocin

\section{METODE}

\section{Jenis dan Rancangan Penelitian}

Penelitian yang dilakukan adalah jenis penelitian eksperimental dengan kelompok perlakuan diberi ekstrak etanol daun MO peroral dengan dosis 250 dan $500 \mathrm{mg} / \mathrm{kg}$ $\mathrm{BB} /$ hari. Rancangan penelitian menggunakan rancangan eksperimental pretest posttest control group design untuk pengukuran kadar gula darah dan post test only control group design untuk pengukuran ketebalan kolagen pada ECM sel $\beta$ pankreas.

\section{Bahan Penelitian}

Subjek penelitian adalah 24 ekor tikus Sprague Dawley yang memenuhi persyaratan (usia 2-3 bulan, jenis kelamin jantan, berat badan 150-250gram, kondisi sehat, tidak terdapat kelainan anatomis, belum pernah digunakan untuk penelitian). Hewan percobaan dibagi menjadi 4 kelompok yaitu: 2 kelompok kontrol negatif (K), 2 kelompok perlakuan (masing-masing kelompok 6 ekor tikus, P1 dan P2). Pakan standar dan minum tikus dengan ekstrak etanol daun MO. Bahan untuk pemeriksaan kadar gula darah dan ketebalan kolagen pada ECM sel $\beta$ pulau Langerhans pankreas yaitu serum darah tikus dan pankreas.

\section{Alat dan Reagensia}

Alat dan reagen yang digunakan dalam penelitian ini antara lain: kandang hewan coba, timbangan digital, sonde lambung, mikroskop cahaya dengan sumber arus listrik, reagen pemeriksaan kadar gula darah dengan metode enzymatic GOD-PAP Diasys, alat untuk pembuatan preparat pankreas, streptozotocin (STZ) dari Nacalay Tesque Inc. Kyoto Japan, reagen pengecatan Van Gieson.

\section{Cara Kerja}

Hewan coba ditimbang berat badannya untuk mengetahui dosis streptozotocin dan dosis ekstrak daun MO. Hewan dipuasakan selama 10-12 jam kemudian diperiksa kadar gula darahnya. Hewan di induksi STZ 40mg/kgBB dilarutkan dalam 0,1M sodium sitrat, $\mathrm{pH} \mathrm{4,5}$. Setelah 2 hari/48 jam dilakukan pemeriksaan kadar gula darah, keberhasilan induksi STZ, kadar glukosa darah puasa $>132$ $\mathrm{mg} / \mathrm{dl}$. Pada hari kedua 6 ekor tikus dari kelompok kontrol dimatikan untuk mengukur ketebalan kolagen pada ECM 
pulau Langerhans pankreas setelah 48 jam induksi STZ. Dua kelompok perlakuan diberi ekstrak etanol daun Moringa oleifera dengan dosis 250 dan 500 $\mathrm{mg} / \mathrm{KgBB} /$ hari. Hewan dipelihara, dan dilakukan pemberian MO sebanyak $2 \mathrm{ml}$ secara sonde selama 21 hari. Setelah di beri MO selama 21 hari tikus di ukur gula darahnya dan dimatikan kemudian diambil pankreas untuk pemeriksaan ketebalan kolagen pada ECM sel $\beta$ pankreas dengan pengecatan Van Gieson.

Pemeriksaan kadar gula darah dilakukan dengan cara tikus dipuasakan selama 10-12 jam, kemudian pengambilan cuplikan darah dari sinus orbita tikus. Serum dalam tabung reaksi diambil dengan mikropipet 10 $\mu \mathrm{L}$ kemudian dimasukkan dalam tabung reaksi, ditambah $1000 \mu \mathrm{L}$ reagen GOD PAP (diays), dicampur (di atas vortex). Sediaan diinkubasi selama 20 menit pada suhu 20$25^{\circ} \mathrm{C}$ dilakukan pembacaan dengan spektrofotometer panjang gelombang $500 \mathrm{~nm}$.

Jaringan hasil eksisi biopsi (pankreas) difiksasi, prosesing selanjutnya potongan jaringan dibuat blok pada parafin padat dengan titik lebur $56-58^{\circ} \mathrm{C}$. Jaringan dalam parafin dipotong setebal 3-4 mikron dengan menggunakan alat mikrotom. Potongan jaringan ditempelkan diatas objek glass. Pewarnaan atau pengecatan dilakukan dengan metode Van Gieson. Skoring kolagen semi kuantitatif pada pengecatan Van Gieson: 0=0-25\%, 1=26-50\%, 2=51-75\%, 3=76-100\%.

\section{Analisis Data}

Analisis deskriptif dilakukan dengan menghitung nilai mean, median dan standar deviasi (SD) terhadap kadar gula darah, ketebalan kolagen pada ECM sel $\beta$ pankreas, selanjutnya disajikan dalam tabel dan grafik. Analisis yang digunakan untuk mengukur kadar gula darah sebelum dan sesudah perlakuan dengan paired test karena distribusi data normal $(P>0,05)$. Uji beda tiap kelompok kadar gula darah dianalisis menggunakan one way ANOVA dilanjutkan uji Post Hoc. Ketebalan kolagen pada ECM sel $\beta$ pankreas dengan uji non parametrik Kruskal-Wallis. Nilai p dianggap bermakna bila $p=0,05$ dengan $95 \%$ interval kepercayaan.

\section{HASIL}

Hasil menunjukkan penurunan kadar gula darah pada kelompok perlakuan pertama dan kedua, sedangkan pada kelompok kontrol tidak ada perubahan kadar gula darah. Penurunan terbesar ditemukan pada perlakuan kedua dengan dosis $\mathrm{MO} 500 \mathrm{mg} / \mathrm{kgBB} / \mathrm{hari}$

Tabel 1. Perbedaan perubahan kadar gula darah antar kelompok

\begin{tabular}{ccccc}
\hline \multirow{2}{*}{ Kelompok } & \multicolumn{4}{c}{ Kadar Gula Darah Mg/DI } \\
\cline { 2 - 4 } & N & \multicolumn{2}{c}{ Mean \pm SD } & $\begin{array}{c}\text { Mean } \\
\text { Delta } \pm \text { SD }\end{array}$ \\
\cline { 2 - 4 } & 6 & $188,24 \pm 5,53$ & $193,33 \pm 3,73$ & $5,17 \pm 2,64^{\mathrm{a}}$ \\
K & 6 & $192,37 \pm 4,81$ & $127,55 \pm 3,85$ & $-64,83 \pm 5,34^{\mathrm{b}}$ \\
P1 & 6 & $189,13 \pm 5,45$ & $115,62 \pm 2,79$ & $-73,50 \pm 6,72^{\mathrm{c}}$ \\
\hline
\end{tabular}

Keterangan: notasi (abc) yang berbeda menunjukkan perbedaan bermakna

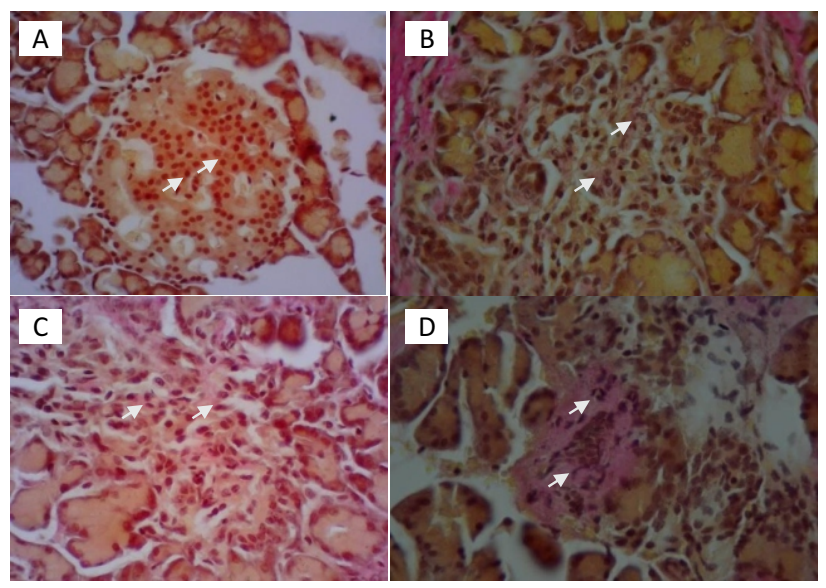

Keterangan: Secara berurutan adalah skor 0-3 kolagen pada ECM sel $\beta$ pankreas. Tampak sel $\beta$ pankreas (A) tidak ada kolagen yang terwarnai di sekitar sel $\beta$ pankreas, tampak kolagen sel $\beta$ pankreas (B) $26-50 \%$ terwarnai, tampak kolagen sel $\beta$ pankreas (C) $51-75 \%$ terwarnai, tampak kolagen sel $\beta$ pankreas (D) 76-100\% terwarnai.

\section{Gambar 1. Gambaran ketebalan kolagen}

Dari 24 sampel pemeriksaan sebanyak 23 sampel (95,8\%) mempunyai ketebalan kolagen pada ECM sel $\beta$ pankreas sebesar $0-25 \%$ dan hanya satu sampel yang mempunyai ketebalan 26-50\%. Secara kuantitatif, didapatkan rerata ketebalan yang sama pada semua kelompok. Gambaran ketebalan kolagen secara kualitatif disajikan pada Gambar 1 untuk menunjukkan skoring ketebalan.

Secara keseluruhan hasil menunjukkan bahwa pemberian ekstrak daun MO peroral dengan dosis $250 \mathrm{mg} / \mathrm{kgBB} /$ hari dan $500 \mathrm{mg} / \mathrm{kgBB} /$ hari dapat menunjukkan penurunan kadar gula darah $(p=0,000)$, tanpa mengakibatkan perbedaan ketebalan ECM sel $\beta$ pulau Langerhans pankreas $(p=0,392)$ yang masih dalam batas normal pada semua kelompok penelitian.

\section{DISKUSI}

Streptozotocin terakumulasi dalam sel beta pankreas melalui afinitas rendah GLUT2 glukosa transporter di membran plasma (7). Dengan sifat alkilasi STZ akan merusak DNA, selanjutnya kerusakan DNA menginduksi aktivasi poli ADP ribosilasi, kemudian poli ADP ribosilasi mengakibatkan deplesi $\mathrm{NAD}^{+}$seluler dan ATP. Deplesi simpanan energi sel akan mengakibatkan nekrosis sel beta pankreas (7). Pemberian terapi obat anti diabetes pada DM tipe 1 berfungsi mengendalikan kadar gula darah (13), sedangkan Moringa oleifera memiliki kemampuan memperbaiki sel $\beta$ pankreas yang mengalami degenerasi $(11,12)$. Derajat kerusakan sel $\beta$ pankreas dapat ditentukan dari pemeriksaan kadar glukosa darah (2).

Pengamatan kadar gula darah selama 21 hari dengan pemberian ekstrak etanol daun Moringa oleifera dosis $250 \mathrm{mg} / \mathrm{KgBB}$ dan dosis $500 \mathrm{mg} / \mathrm{KgBB}$ menunjukkan bahwa kadar gula darah dapat menurun akibat pemberian ekstrak etanol daun Moringa oleifera. Hal ini diperjelas dengan kadar gula darah pada kelompok perlakuan dosis $500 \mathrm{mg} / \mathrm{KgBB}$ yang berada pada nilai normal dibandingkan kontrol. Penurunan kadar gula darah diduga terjadi akibat dari perbaikan sel $\beta$ pankreas oleh ekstrak etanol daun Moringa oleifera, karena daun Moringa oleifera memiliki kandungan Gallic tannins, Steroids and triterpenoids, 
Flavonoids, Saponins, Anthraquinones, Reducing sugars (13-15). Antioksidan yang terdapat dalam Moringa oliefera antara lain vitamin C dan flavonoid (14-16), sehingga daun Moringa memiliki aktivitas yang kuat sebagai scavenger oksidan yang mampu menghambat reaksi oksidasi ROS dan meningkatkan aktivitas SOD, GSH dan katalase yang menyebabkan penurunan stres oksidatif dalam sel (14). Selain itu daun MO memiliki kandungan berbagai vitamin, mineral dan asam amino esensial yang berguna dalam regenerasi sel $(8,16)$.

Penurunan stres oksidatif dalam sel berarti menurunkan proses kerusakan/degenerasi sel $\beta$ pankreas sehingga akan mempercepat proses regenerasi sel $\beta$ pankreas (4). Triterpenoid yang ditemukan pada daun Moringa oleifera diduga mampu menstimulasi sekresi insulin dari sel $\beta$ pankreas ke sirkulasi darah (9). Ekstraksi dengan etanol akan mengekstraksi semua senyawa kimia/bioaktif yang ada pada daun Moringa oleifera, yaitu flavonoid, sterol, triterpenoid, alkaloid, saponin dan fenolat, reducing sugar yang diduga dari masing-masing senyawa itu memiliki cara kerja yang saling bersinergi dalam pengendalian hiperglikemik $(9,17)$.

Pemberian STZ satu kali dengan dosis $40 \mathrm{mg} / \mathrm{KgBB}$ intraperitonial tidak menunjukkan peningkatan ketebalan kolagen ECM sel $\beta$ pulau Langerhans pankreas pada kelompok kontrol dan ketebalan masih dalam batas normal (0-25\%). Dalam kemampuan regenerasi serta hubungannya dengan siklus sel, pankreas termasuk sel stabil yang mampu berespon dengan cepat dengan membelah diri ketika terpapar cedera (18). Struktur ketebalan kolagen (0-25\%) pada kelompok kontrol dan

\section{DAFTAR PUSTAKA}

1. Shaw JE, Sicree RA, and Zimmet PZ. Global Estimates of the Prevalence of Diabetes for 2010 and 2030. Diabetes Research and Clinical Practice. 2010; 87(1): 4-14.

2. Purnamasari D. Diagnosis dan Klasifikasi Diabetes Melitus. Di dalam: Sudoyo AW, Setiyohadi B, Alwi I, Simadibrata M, and Setiati S (Eds). Buku Ajar IImu Penyakit Dalam edisi 5. Jakarta: Internal Publishing; 2009; hal. 1880-1883.

3. Salzier MJ, Crawford JM, and Kumar V. Pankreas. Di dalam: Kumar V, Cotran RS, and Robins SL (Eds). Buku Ajar Patologi volume 2 edisi 7. Jakarta: EGC; 2007: hal. 718-731.

4. Kangralkar VA, Patil SD, and Bandivadekar RM. Oxidative Stress and Diabetes: A Review. International Journal of Pharmaceutical Applications. 2010: 1(1): 38-45.

5. Amin A, Lotfy M, Ghoneim DM, et al. PancreasProtective Effects of Chlorella in STZ-Induced Diabetic Animal Model: Insights into the Mechanism. Journal of Diabetes Mellitus. 2011; 1(3): 36-45.

6. Krishnamurthy M, Li J, Al-Masri M, and Wang R. Expression and Function of AB1 Integrins in Pancreatic Beta (INS-1) Cells. Journal Cell Communication and Signaling. 2008; 2(3-4): 67-79.

7. Ali S, Rohilla A, Dahiya A, Kushnoor A, and Rohilla S. Streptozotocin Induced Diabetes: Mechanisms of Induction. International Journal of Pharmaceutical perlakuan ternyata sel beta pankreas mempunyai fungsi yang berbeda yaitu kadar gula kelompok perlakuan lebih rendah secara bermakna dibanding kelompok kontrol. Walaupun struktur kolagen pada ECM sel beta pankreas belum mengalami kerusakan namun fungsi sel beta pankreas yang memproduksi insulin untuk mengendalikan kadar gula darah pada kelompok kontrol sudah mengalami penurunan. Perpaduan signal ECM dengan reseptornya, sel dan hormon dengan reseptornya berperan penting dalam mempertahankan struktur dan fungsi (19). Keterpaduan sinyal ECM, reseptor, sel $\beta$ dan hormon insulin kemungkinan mengalami gangguan karena sel beta pada kelompok kontrol sudah mengalami kerusakan akibat induksi STZ sehingga tidak mampu mengendalikan hiperglikemia.

Berdasarkan hasil penelitian, diketahui bahwa pemberian ekstrak etanol daun Moringa oliefera dosis $500 \mathrm{mg} / \mathrm{KgBB} / \mathrm{hari}$ dapat menunjukkan penurunan kadar gula darah sampai nilai normal pada tikus yang di induksi streptozotocin di banding kelompok kontrol. Pemberian STZ satu kali dengan dosis $40 \mathrm{mg} / \mathrm{KgBB}$ intraperitonial tidak menunjukkan peningkatan ketebalan kolagen pada ECM sel $\beta$ pulau Langerhans pankreas pada kelompok kontrol yang teramati dalam 23 hari pasca induksi dan ECM khususnya kolagen pada sel $\beta$ pankreas masih dalam batas normal. Efek samping terhadap pemberian daun kelor (Moringa oliefera) belum diketahui dengan jelas, sehingga diperlukan penelitian lebih lanjut untuk mengetahui efek samping. Perkembangan selanjutnya, dapat dilakukan pengujian klinis dan keamanan Moringa oleifera sebagai obat alternatif untuk pengendalian hiperglikemia pada manusia.

Research and Development. 2011; 4(4): 11-15.

8. Tilong AD. Ternyata, Kelor Penakluk Diabetes. Yogjakarta: Diva Press; 2012.

9. Tende JA, Ezekiel I, Dikko AUU, and Goji DT. Effect of Ethanolic Leaves Extract of Moringa Oleifera on Blood Glucose Levels of Streptozocin-Induced Diabetics and Normoglycemic Wistar Rats. British Journal Pharmacology and Toxicolology. 2011; 2(1): 1-4.

10. Mishra G, Singh, Verma R, Kumar S, Srivastav S, Jha, and Khosa. Traditional Uses, Phytochemistry and Pharmacological Properties ff Moringa Oleifera Plant: An Overview. Der Pharmacia Lettre. 2011; 3(2): 141164.

11. Gupta R, Mathur M, Bajaj VK, et al. Evaluation of Antidiabetic and Antioxidant Activity of Moringa oleifera in Experimental Diabetes. Journal of Diabetes. 2012; 4(2): 164-171.

12. Jaiswal D, Kumar Rai P, Kumar A, Mehta S, and Wata G. Effect of Moringa oleifera Lam. leaves Aqueous Extract Therapy on Hyperglycemic Rats. Journal of Ethnopharmacology. 2009; 123(3): 392-396.

13. Soegondo S. Farmakoterapi pada Pengendalian Glikemia Diabetes Melitus Tipe 2. Di dalam: Sudoyo AW, Setiyohadi B, Alwi I, Simadibrata M, dan Setiati S (Eds). Buku Ajar Ilmu Penyakit Dalam Edisi 5. Jakarta: Internal Publishing; 2009; hal. 1884-1890.

14. Shih MC, Chang CM, Kang SM, and Tsai ML. Effect of Different Parts (Leaf, Stem and Stalk) and Seasons (Summer and Winter) on the Chemical Compositions 
and Antioxidant Activity of Moringa oleifera. International Journal Molecular Sciences. 2011; 12(9): 6077-6088.

15. Sushma G, Shivaprasad HN, Nargund LVG, Bharumathy $\mathrm{M}$, and Midun T. Moringa oleifera Attenuates Oxidative Stress in STZ-Induced Diabetic Rats. International Journal for Pharmaceutical Research Scholar. 2013; 2(1): 36-44

16. Divi MS, Bellamkonda R, and Dasireddy SK. Evaluation of Antidiabetic and Antihyperlipedemic Potential of Aqueous Extract of Moringa Oleifera in Fructose Fed insulin Resistant and STZ Induced Diabetic Wistar Rats: A Comparative Study. Asian Journal Pharmaceutical and Clinical Research. 2012; 5(1): 6772.
17. Kasolo KN, Bimenya GS, Ojok L, Ochieng J, and OgwalOkeng JW. Phytochemicals and Uses of Moringa oleifera Leaves in Ugandan Rural Communities. Journal of Medicinal Plants Research. 2010; 4(9): 753757.

18. Mitchell RD and Cotran RS. Pemulihan Jaringan: Regenerasi dan Fibrosis Sel. Di dalam: Kumar V, Cotran RS, and Robins SL (Eds). Buku Ajar Patologi Volume 1 Edisi 7. Jakarta: EGC; 2007: hal. 65-84.

19. Hansen RK and Bissell MJ. Tissue Architecture and Breast Cancer: The Role of Extracellular Matrix and Steroid Hormones. Endocrine-Related Cancer. 2000; 7(2): 95-113. 